\title{
TUGAS FILSAFAT MORAL
}

\section{"PEMBUNUHAN GURU HONORER KEDIRI"}

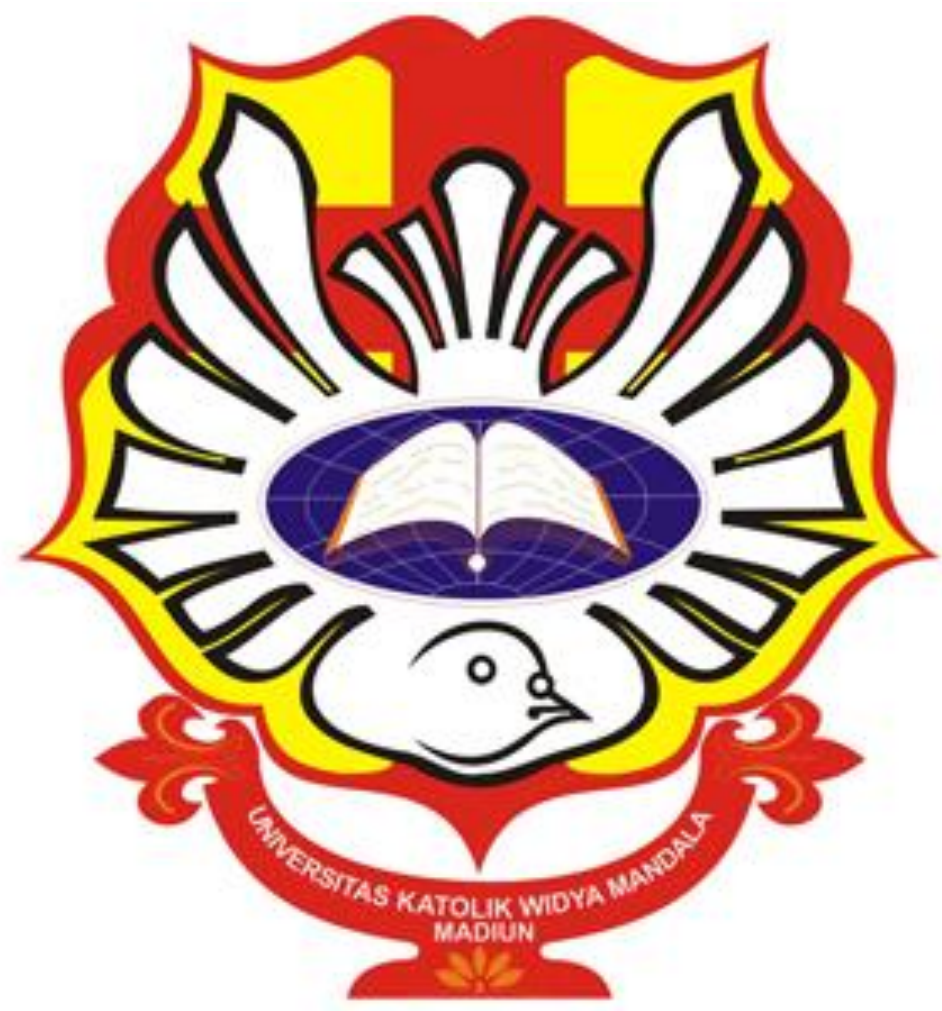

DISUSUN OLEH :

32318404 BAYU ANDI NUGROHO

D3 FARMASI REGULER SORE

UNIVERSITAS KATOLIK WIDYA MANDALA MADIUN

TAHUN 2018/2019 


\begin{abstract}
ABSTRAK
Indonesia adalah Negara yang beragama,manusia diciptakan pertama kali adalah Nabi Adam as dan Siti Hawa hal pertama yang dilakukan mereka adalah mencari dedaunan untuk menutup aurat dan memperkecil hawa nafsu. Manusia sekarang tidak mengenal rasa malu dengan menggunakan pakaian yang seksi yang mengundang hawa nafsu . Kaum homoseksual yang disebut kaum Sodom yaitu umat Nabi Luth as. Kaum homoseksual dan lesbi tidak bisa berinteraksi dengan bebas untuk mencari teman dan bahkan kekasih sesama jenis. Di Kabupaten Blitar ditemukan jasad seorang pria yang setengah bugil, jasad itu adalah korban dari pembunuhan yang sisertai mutilasai oleh kekasih sesame jenis. Pembunuhan yang disertai mutilasi didasari oleh masalah permintaan korban terhadap pelaku yang tidak bisa dipenuhi dan akhirnya terjadi pertengkaran hingga pada akhirnya korban dibunuh.
\end{abstract}

Keyword : Pembunuhan,Guru,Honorer 


\section{BAB I \\ PENDAHULUAN}

\section{A. Latar Belakang}

Manusia diciptakan pertama kali adalah Nabi Adam as dan Siti Hawa, untuk menutup aurat dan memperkecil hawa nafsu yang dapat menumbulkan perzinahan yang dilarang Allah SWT hal pertama yang dilakukan mereka adalah mencari dedaunan. Namun berbanding terbalik pada zaman sekarang, manusia sekarang tidak mengenal rasa malu dengan menggunakan pakaian yang seksi yang mengundang hawa nafsu.

Pada zaman para Nabi sudah dikenal kaum homoseksual yang disebut kaum Sodom yaitu umat Nabi Luth as. Bahkan dizaman sekarang banyak Negara yang mengeluarkan hokum politik atas perkawinan sesama jenis.

Pada dasarnya setiap manusia mempunyai masalah-masalah sosial budaya,biasanya masalah itu merupakan masalah yang negative, misalnya homoseksual dan lesbi.

Homoseksusal dan lesbian di Indonesia kini mulai ramai diperbincangkan seperti halnya kasus pembunuhan guru honorer dikediri, antara koban dan pelaku merupakan teman dalam sebuah komutas kaum homoseksual.

Kaum homoseksusal dan lesbian tidak bisa berinteraksi dengan bebas untuk mencari teman dan bahkan kekasih sesama jenis, mereka mencari teman dan pasangan umumnya dilakukan dimedia sosial. Kaum homoseksual atau gay membutuhkan dukungan dari teman senasib untuk berbagi dan tempat mengadu. Kaum homoseksusal ataupun lesbi tidak sembarangan dalam menentukan pasangan karena mereka ragu bahkan takut untuk mengungkapkan perasaan suka terhadap sesama jenis, dan akhirnya mereka menggunakan media sosial untuk mengungkapkan rasa yang mereka rasakan dan merekapun melakukan pertemuan untuk saling mengenal satu sama lain.

Di Negara Indonesia kaum homoseksual dan lesbi menurut hukum dan agama mereka tidak diperbolehkan mungkin ini yang menyebabkan mereka sembunyi-sembunyi dalam menjalin hubungan terlarang.

\section{B. Rumusan masalah.}

1. Pembunuban guru honorer Kediri.

2. Motif pembunuhan Kronologi pembunuhan.

3. Pembunuhan guru honorer ditinjau dari moral.

4. Bagaimana tindakan pemerintah dalam kasus ini. 


\section{BAB II \\ PEMBAHASAN}

\section{Pembunuhan guru honorer di Kediri .}

Kabupaten Blitar Kecamatan Udanawu desa Karang Gondang dihebohkan dengan ditemukannya manyat laki-laki pada rabu 3 April 2019 saat ditemukan kondisi jasad korban begitu mengenaskan didalam koper.

Jasad korban ditemukan tanpa kepala dengan kondisi bugil,jasadnya ditekuk dan berada dalam koper berwarna hitam yang dibuang ke semak-semak. Penemuan jasad tersebut kemudian dibawa kerumah sakit untuk diperiksa lebih lanjut. Pihak keluarga membawa jasad yang sudah diketahui identitasnya tersebut untuk dimakamkan meski tanpa kepala pada kamis 4 april 2019.

Jasad yang diketahui identitasnya tersebut adalah seorang guru honorer di sekolah dasar dan merupakan seorang penari.Jasad yang diketahui bernama Budi Hartanto tersebut mengajar di SD Banjarmlati 3 Kediri.Iya juga memiliki sanggar tari untuk perlajar dan umum dan dia juga mengajar tari.

Paman Budi bersaksi, Budi meninggalkan rumah dengan membawa tas yang berisi Laptop dan uang yang tidak bisa dibilang sedikit. Pemeriksaanpun dilakukan didalam kamar Budi oleh pihak kepolisian,buku tabungan hingga surat berharga diambil dengan tujuan agar kasus ini bisa terungkap.

Pada Kamis 11 April 2019 kasus pembunuhan Budi Hartanto mulai terungkap setelah pelakunya ditangkap. Diketahui pembunuh Budi Hartanto ada dua orang yaitu Aris Sugianto alias AS alias AP dan Aji Prakoso alis AJ, pelaku AP ditangkap pada pukul 07.50 WIP pada saat berada dalam bus di Tol kota Tegal Parang,Jakarta Selatan dan pelaku yang berinisial AJ dapat ditangkap polisi kota Kediri.

Setelah ditangkap pelaku yang berisial AP mengungkapkan pernyataan yang mengejutkan dalam video yang tengah viral. 
Video yang diungggah pada 13 April 2019 oleh akun Facebook Chand Eindah, tersangga AP alias AS yang terlihat memakai baju hitam membantah ikut dalam memutilasi Budi Hartono.

Guru honorer Budi Hartono yang tewas hingga akhirnya dibuang ke Blitar juga dibeberkan oleh Tersangka AP alias AS. Menggunakan dua senjata yaitu celurit dan bendo pelaku mengakui perbuatannya tapi membantah melakukan mutilasi pada korban.

AP alias AS mengakui dalam kasus pembunuhan ini tugasnya hanya memegangi korban, yang memutilasi hanya satu orang .

Setelah dieksekusi potongan kepala korban dibuang di sungai yang diakui oleh pelaku, setelah ditanya polisi pelaku mengaku bahwa ada dua orang yang melakukan eksekusi.

\section{Motif pembunuhan}

Asmara atau cinta antara pelaku dengan korban diduga menjadi pemicu pembunuhan sadis yang dikatakan oleh Kabid Barung Mangeran pada Jum'at 12 April 2019.

Dalam sebuah komunitas pelaku dan korban merupakan terman dekat, terang Barung mereka pernah memiliki hubungan spesifik dengan orientasi pada komunitas. Barung juga mengungkapkan bahwa korban juga sering berganti pasangan dan mempunyai banyak pacar.

Budi berkenalan dengan Aris Sugianto melalui sosial khusus gay setahun yang lalu, yang mana Aris sebagai perempuan dan Budi sebagai laki-lakinya. Aris mengaku bahwa sangat mencintai Budi sehingga Aris sanggup memberikan apapun yang diminta Budi.

Setelah kasus ini terungkap ternyata Aris dan Budi sudah sebanyak empat kali melakukan hubungan badan, sebanyak tiga kali dilakukan di rumah Aris daerah Mangunan Udanawu Blitar dan yang terakhir dilakukan di warung Aris.

Selasa 2 April 2019 sekitar pukul 22.00 WIB setelah berhubungan badan di dalam warung milik Aris, antara pelaku dan korban terjadi pertengkaran yang disebabkan Aris tidak bisa memberikan uang yang diminta Budi. 
Karena Aris tidak bisa memberikan sejumlah uang yang diminta Budi setelah melakukan hubungan badan, Budipun marah-marah, Aziz yang merupakan teman Aris ditampar korban karena berusaha menegur pertengkaran Aris dengan Budi.

Budi kemudian mengambil golok sepanjang $10 \mathrm{~cm}$ yang akan dikibaskan kearah Aziz dikarenakan Budi tidak terima setelah Aziz membalas tamparan dari Budi. Budi berusaha menyerang Aziz dengan menggunakan golok tapi Aziz bisa menangkis dan merebut golok itu

Azizpun membabat tubuh Budi Hartono yang jatuh tertelungkup dengan berteriakteriak dan pada saat itu Aziz menyabetkan berkali-kali golok ke tubuh Budi. Aris membantu Aziz dengan menyumpal mulut Budi yang merupakan orang dicintainya sekarat.

Budi akhirnya tewas kemudian Aris dan Aziz memutilasi kepala korban dan membuang ke sungai sedangkan badan korban dibuang ke bawah jembatan daerah Karang Gondang Udanawu Blitar yang dimasukkan dalam koper untuk menghilangkan jejak pembunuhan.

Hubungan percintaan antara korban dengan pelaku sangantlah rumit, karena melihat kekasihnya di bantai bukannya membela tetapi malah membantu proses pembunuhan itu.

\section{Pembunuhan guru honorer ditinjau dari sudut pandang moral.}

Apakah perkara etika itu merupakan kebahagiaan? Perkara etika merupakan suatu kebahagiaan karena hidup bahagisa itu merupakan tujuan dari setiap manusia.Lapangan penjelajahan etika merupakan hidup manusia dan bidang penyelidikan etika yang paling penting adalah kebahagiaan sebagai target perbuatan manusia.

Menurut Aristoteles tema pleasure mendahului happiness, menurutnya kenikmatan merupakan salah satu realitas sehari-hari dalam hidup manusia. Tema penting etika adalah kenikmatan. "for it seems to be especially proper to our kind, and hence, when we educate children we steer them by pleasure and pain [karena tampaknya benar bahwa kita mendidik anak-anak dalam kaitannya dengan kenitnamatn dan penderitaan] (172a20)". Manusia pada prinsipnya akan menghindari penderitaan untuk mengejar kenikmatan namun tidak semua kenikmatan itu jelek tergantung bagaimana manusia 
menyikapinya. "Every faculty of perception is active in relation to its perceptible object, and completely active when it is in good condition is relation to the finest of its perceptible objects". Bagi Aristoteles, soal rasa bukan merupakan arti pertama dari kenikmatan melaikan sebuah aktivitas.

Menurut Aristoteles keadaan bahagia itu belum tentu dikatakan suatu kebahagiaan, "Happiness is not a state. For, if it were, someone might have it and yet he asleep for his whole life" (1176a34).

Kebahagiaan itu bukan soal keadaan karena jika itu keadaan orang yang sudah menikmatinya akan sepanjang hidupnya tidur maka dari itu kata yang tepat soal kebahagiaan adalah menyangkut suatu aktivitas.

Menurut Aristoteles sangat penting mengutamakan akal budi karena dalam arti Aristotelian mengandaikan akal budi yang baik yaitu practical wisdom.

Kasus pembunuhan guru honorer Budi Hartanto merupakan akibat dari suatu kenikmatan yang menyangkut kebahagiaan yang tidak disertai akal budi.Jika memang mempunyai akal budi yang baik, membedakan hal yang buruk dan hal yang baik tentu sudah tidak asing lagi. Seorang guru tentunya menjadi cohtoh bagi para muridnya, tentu contoh yang diberikan harus contoh yang baik bukan merupakan contoh yang buruk.

Dalam kasus ini jelas terlihat bahwa korban dan pelaku mengejar suatu kenikmatan yang tidak didasarkan pada etika hingga mengorbankan jatuhnya korban jiwa. Karena akal budi yang sudah tidak dipakai membunuh orang seakan-akan merupakan harl yang wajar.

Dalam islam berhubungan sesama jenis hukumnya haram.Dalam kitab agama islam penyuka sesame jenis antara pria dengan pria disebut "liwaath". Dan dikategorikan perbuatan keji. Dalam surat al-A'raaf ayat 80 dan 81 "Dan (kami telah mengutus) Luth, ketika ia berkata kepada kaumnya: "mengapa kamu mengajarkan perbuaatan faakhisyah itu, yang belum pernah dikerjakan oleh seorang pun sebelumnya. Sesungguhnya engkau mendatangi laki-laki untus melepaskan nafsumu, bukan kepada wanita. Sungguh kamu ini kaum yang melampaui batas”.

Kenikmatan menuju suatu kebahagiaan boleh saja asal didasarkan pada etika dan norma-norma dan juga sesuai dengan aturan baik hukum maupun aturan agama. Apa 
yang dilakukan guru honorer dan para pelaku memang semata-mata mencari kenikmatan namun apa yang mereka lakukan untuk meraihnya dengan cara yang menyimpang, apa yang dilakukan dengan cara yang salah akan menuai akibat yang buruk dari perbuatan itu sendiri.

\section{Bagaimana tindakan pemerintah dalam kasus ini.}

Pembunuhan yang disertai mutilasi terhadap guru honorer langsung ditangani oleh kepolisian daerah jatim (Polda Jatim) dan diduga kasus pembunuhan ini merupakan pembunuhan berencana.

Pelaku diketahui telah menyiapkan alat lebih dulu sebelum membunuh korbannya, berdasarkan hasil forensic yang disebut oleh kepala bidang hubungan masyarakat polda jatim komisaris besar polisi Frans Barung.

Komisaris besar itu juga mengatakan bahwa pemotongan kepala dilakukan pada saat korban meninggal dalam kondisi luka. Tangan yang tergores muncul karena korban menangkis serangan pelaku.

Beliau juga menambahkan dua dugaan kembali muncul melatarbelakangi pemenggalan kepala korban, yang pertama untuk meninggalkan jejak dan yang lainnya koper yang digunakan tidak muat jika kepalanya tidak dipotong.

Guna kepentingan penyidikan personel dari Direktorat Resor Kriminal Umum (Ditreskrimum) Polda Jatim dan personel Polres Kediri diterjunkan untuk memburu terduga pelaku pembunuhan yang disertai mutilasi tersebut.

Pembunuh Budi Hartanto ada dua orang yaitu Aris Sugianto alias AS alias AP dan Aji Prakoso alis AJ, pelaku AP ditangkap pada pukul 07.50 WIP pada saat berada dalam bus di Tol kota Tegal Parang,Jakarta Selatan dan pelaku yang berinisial AJ dapat ditangkap polisi kota Kediri. 


\section{BAB III \\ DAFTAR PUSTAKA}

Begini Kronologi Sebenarnya Pembunuhan Guru Honorer Kediri Available from : http://www.tribunnews.com/regional/2019/04/13/begini-kronologi-sebenarnya-pembunuhanguru-honorer-kediri

Pada tanggal 26 Juni 2019

\section{Fakta Terbaru Pelaku Mutilasi Guru Honorer Kediri, Korban Tewas Dibekap,} Pelaku Sayang Korban Available from : http://www.tribunnews.com/regional/2019/04/15/11-fakta-terbaru-pelaku-mutilasi-guru-honorerkediri-korban-tewas-dibekap-pelaku-sayang-korban

Pada tanggal 27 Juni 2019

Pelaku Mutilasi Punya Hubungan Asmara dengan Guru di Kediri Available from : https://www.cnnindonesia.com/nasional/20190415170527-12-386572/pelaku-mutilasi-punyahubungan-asmara-dengan-guru-di-kediri

Pada tanggal 30 Juni 2019

Mutilasi Guru Honorer Asal Kediri Diduga Pembunuhan Berencana Available from : https://www.cnnindonesia.com/nasional/20190408132026-12-384237/mutilasi-guru-honorer-asalkediri-diduga-pembunuhan-berencana

Pada tanggal 30 Juni 2019

Dewantara, A. (2017). Filsafat Moral (Pergumulan Etis Keseharian Hidup Manusia).

Dewantara, W. A. (2017). filsafat Moral. Daerah Istimewa Yogyakarta: penerbit PT Kanisius. ISSBN, 978-979.

Hari, A., \& Dewantara, A. (2019). Berita Hoax Tentang Politik Di Indonesia Terhadap Perkembangan Negara Disorot Dengan Teori "Actus Humanus" Filsafat Moral.

Sabarwati, O. (2019). Filsafat Etika Moral tentang Penganiayaan.

Gunawan, D. (2019). HOAXS KASUS RATNA SARUMPAET.

Wima, S. M. D. F. (2019). Serangan Hoax Dan Provokasi Ke Berbagai Aspek Kehidupan Disorot Dalam Sudut Kemoralan. 